\title{
The Development of Gnomonia erythrostoma, Pers. The Cherry-Leaf-Scorch Disease.
}

\author{
BY \\ F. T. BROOKS, M.A. \\ Senior Demonstrator of Botany, Cambridge University.
}

With Plates XLVIII and XLIX.

T N 1886 Frank (17) gave a short account of the development of this 1 Pyrenomycete and showed that it was the cause of an epidemic disease of Cherry trees in the district of Altenlande in Germany. The chief features of the life-history of the fungus as described by Frank may be summarized as follows :-

Infection of the leaves first takes place in the spring, and the mycelium which develops in them passes towards the base of the leaf-stalks where it prevents the formation of the absciss layer. By this means infected leaves do not fall in the autumn but remain hanging on the trees to cause infection of the new foliage in the following spring. Where the mycelium is present in the leaves, spermogonia giving rise to spermatia, and coiled structures with trichogynes, are found. Frank considers that the spermatia fertilize the coils, after which the latter develop into perithecia which liberate their spores in the spring. Frank's brief account only dealt with the grosser development of the fungus, and it was obvious that a cytological investigation was to be desired. The absence of figures of the ascogonia, trichogynes, \&c., in Frank's account, and the lack of detailed knowledge of the development of the perithecium of the Pyrenomycetes generally, made this all the more imperative.

The present investigation was begun at the suggestion of Professor V. H. Blackman, to whom I am much indebted for advice and criticism.

Material was obtained from the Cherry-growing districts of Kent, where the disease caused by Gnomonia erythrostoma is known as the 'Cherry Leaf Scorch' on account of the appearance presented by the retained foliage of infected trees in autumn and winter. At the outset of the investigation attempts were made at Cambridge to cause infection of some of the varieties of Cherries most susceptible to this disease. For this purpose specimens of such trees were obtained, and in the spring, at the

[Annals of Botany, Vol. XXIV. No. XCV. July, I9Io.] 
time when the new foliage was appearing, cherry-leaves containing the ripe perithecia of the fungus-likewise obtained from Kent-were damped and hung on the trees. Frank has shown that the perithecia when alternately damped and dried liberate their spores by successive ejaculations. I confirmed this by placing damp leaves bearing perithecia in Petri dishes; when the leaves had become dry it was found that the ascospores had collected in groups of eight on the lid of the dish. Thus when leaves bearing mature perithecia were damped and hung on the trees it was considered that the conditions approximated to those under which infection ordinarily occurred in nature. Later on in the summer it was found that a few leaves had become infected. The number of infected leaves, however, was insufficient to provide material in different stages, so several journeys were made to Kent for the purpose of obtaining further supplies. During these visits some observations were made on the relative susceptibility and immunity of different cultivated varieties of Cherry trees. It was found that the following kinds of sweet cherries are attacked by the disease to the greatest extent:-Florence, Waterloo, and Frogmore, while Elton Heart and Black Heart are only slightly attacked, and Amber, Turk, and Crown varieties are apparently immune from the disease. ${ }^{1}$ These observations are in agreement with those of Salmon (27).

Thus the ' Cherry Leaf Scorch' is another of those diseases which affect different cultivated varieties of the host species to very different degrees. As yet, practically nothing is known as to the factors which confer immunity upon some varieties.

Upon making inquiries I found that the 'Scorch' disease is now much less prevalent in Kent than formerly. This is due to the commendable practice in many orchards of destroying from year to year the leaves found hanging on the trees in winter. It has been well known since Frank's first account of the disease, that the leaves which hang on the trees in winter are the only means by which a new infection can take place.

In one or two plantations visited, these measures had not been taken for the destruction of the disease. It was here noticeable that the trees susceptible to the disease produced only a very meagre quantity of fruitthe natural consequence of the weakening of the trees by the presence of the fungus for several years-and the cherries that were formed became hard, distorted, and spotted. Such cherries never became properly ripe.

\section{External Appearance of Leaves affected by the Parasite in its Early Stages of Development.}

Great difficulty was experienced at first in finding leaves in the early stages of attack. Little help was obtainable from Frank's account as

\footnotetext{
${ }^{1}$ Acid cherries also remain free from attack.
} 
he describes the external features of the disease with extreme brevity. After considerable trouble, however, I was able to find Cherry leaves which contained the parasite in the very young stages of development. The first signs of disease are the presence of faint yellowish patches either on the margin or near the midrib of the leaves, though when these patches are seen for the first time they hardly suggest disease of a serious nature.

On cutting hand sections through leaves affected in this way the characteristic mycelium of Gnomonia erythrostoma could be discerned. These yellowish patches are first recognizable in the early part of July. They increase in size and become more clearly yellow in colour. Towards the end of August spermogonia become visible. They are formed in enormous numbers, and appear externally as tiny circular spots on the under surface of the yellowing parts of the leaves and just visible to the naked eye. With the production of spermogonia the diseased portion of the leaf becomes brown.

\section{Methods.}

Portions of diseased cherry leaves were fixed in various fluids. Flemming's weaker and stronger solutions, Gilson's fluid, Juel's fluid, and acetic alcohol were tried, but as the first-named solution proved to be by far the most satisfactory fixative it was generally used. An air-pump to aid fixation was employed when necessary. The material was cleared in chloroform or in cedar oil and embedded in paraffin of about $52^{\circ} \mathrm{C}$. melting point. Microtome sections were cut from $5 \mu-15 \mu$ in thickness and were stained either in gentian violet and orange $G$, or in Heidenhain's iron-alum-haematoxylin, with a counter-stain of orange $G$, congo red, or erythrosin.

\section{Vegetative Mycelium.}

Frank (17) states that the ascospore on germinating upon the surface of the leaf gives rise to an appressorium, a structure which doubtless performs mainly an anchoring function. The appressorium puts out a short tube which penetrates the cuticle directly, thus entering an epidermal cell. The parasite enters the intercellular spaces of the mesophyll by means of another short hypha which penetrates the inner wall of the epidermal cell. Evidence of the production of appressoria and of the penetration of epidermal cells was also seen in my preparations of the young mycelium.

The subsequent development of the mycelium is intercellular. A general view of it is seen in Plate XLVIII, Fig. I. The mycelium consists of broad hyphae which are septate and branch at intervals; it ramifies most abundantly in the spongy parenchyma, but not infrequently branches are put out which force their way between the closely packed palisade cells. Narrowings 
of the hyphae occur frequently when they intrude between the host cells. It is often observed that cells of the parasite are very closely attached to cells of the host. In such cases it appears that the wall of the fungus cell becomes somewhat gelatinized so that the contact can be more intimate. Haustoria, however, were never seen. After a time the host cells, which are in intimate contact with the fungus, shrivel and die. Such disorganization of the host cells is seen particularly well where a branch of the general mycelium penetrates the palisade region of the leaf. It is obvious that the fungus kills the host cells gradually. On the other hand, the parasite does not remain in intimate connexion with living cells of the host over such a long period of time as is the case with Rust Fungi, where, of course, haustoria are developed. The chlorophyll granules of the cells of the Cherry leaves in the neighbourhood of the mycelium are smaller in size than granules in healthy parts, and they are yellowish in colour.

On cutting hand sections of fresh material, it is seen that the hyphae of the parasite are filled with extremely granular protoplasm. In stained preparations the cells are found to be multinucleate, as will be seen by an examination of Fig. I. Some cells contain as many as fifteen nuclei, but the general number is from five to eight. The multinucleate nature of the cells of this fungus is thus the same as that found in Humaria gramulata (3), Aspergillus herbariorum (20), and many other Ascomycetes, though different from the uninucleate condition of the cells in the Mildews (22). It is very doubtful, however, whether any phylogenetic significance is to be attributed to the uninucleate or multinucleate nature of vegetative cells in the Ascomycetes.

The nuclei of Gnomonia erythrostoma are small, but, in spite of this, they show a fair amount of structural detail-much more in fact than the vegetative nuclei of many other fungi as yet examined. The vegetative nucleus contains several small, deeply staining, granules found generally near the nuclear membrane, and in some cases a distinct though faint reticulum can be seen (Fig. 2); a nucleolus may or may not be present. In many other fungi (e. g. the Rusts), the only portion of the vegetative nucleus which takes up the stain with ease is the nucleolus, so that, apart from the latter, the nucleus appears homogenous.

Apart from the divisions in the ascus and ascospore to be described later, the nuclei have been only rarely seen undergoing the process of division, and in these cases details could not be made out.

After the mycelium has ramified in the leaves for some weeks, spermogonia and the coiled structures (Knäuel verflochtener Fäden) described by Frank are formed. Although the two sets of structures overlap in development, some spermogonia always appear first. 


\section{The Spermogonia.}

These are produced in enormous numbers on the under surface of the affected leaf-areas. Their external appearance has been already described. Occasionally two spermogonia coalesce to form a compound structure. The wall of the spermogonium consists of very closely compacted hyphae which form a kind of pseudoparenchyma. From the interior of the spermogonium, hyphae grow out towards the small circular orifice. These hyphae even at the base are much narrower than the vegetative hyphae, and they quickly taper to a point. The spermatia are formed by abstriction from the extremities of these hyphae. A general view of a section through a spermogonium is seen in Fig. 3, a portion of which is shown on a more highly magnified scale in Fig. 4. The cells which give rise to spermatia are uninucleate, the single nuclei being larger and showing a more clearly defined network than the vegetative nuclei. The hyphae from which the spermatia originate, are often unbranched, though sometimes branching may occur as seen in Fig. 4. There is some evidence that more than one spermatium can be abstricted successively from the apical region of the spermogonial hyphae. In a mature spermogonium a few hyphae are seen to be distinguished from those giving rise to spermatia by growing further towards the orifice, and by their more deeply staining character. It is likely that these hyphae aid in the extrusion of the spermatia.

The material was not favourable for observing details of the nuclear division which occurs prior to the abstriction of a spermatium. After this division, the daughter-nucleus which will become the nucleus of the spermatium rapidly becomes elongated. After separation of the spermatium from the hypha, the nucleus of the former is long and thread-like, and occupies a large part of the space within the wall. A relatively small amount of cytoplasm is present, most of which is found towards the lower end of the spermatium (Fig. 6). Under high magnifications the thread-like nucleus is seen to be not quite homogeneous, some portions staining more deeply than other (Fig. 6).

The spermatia are straight at the time of formation, but most of them become curved to different degrees upon liberation from the spermogonium. Fig. 5 shows the diversity of form assumed by the spermatia. Sometimes the spermatium has the hooked shape of the spermatium of Polystigma rubrum (15), but more often the amount of curvature is only slight. The spermatia are from $8 \mu-\mathrm{I} 8 \mu$ in length by about $0.5 \mu$ broad. Frank gives the length of the spermatia as $14 \mu-16 \mu$, but my experience is that the diversity in length is much greater than this. They are very slightly broader at one extremity than at the other, but the difference in this respect is much less marked than is the case with the spermatia of Polystigma rubrum. 
A very large number of spermatia are produced within a spermogonium. They extrude from the orifice in a short coiled thread. The pycnidia of many other Pyrenomycetes (e. g. Valsa) and of certain members of the Sphaeropsidales (e.g. Cytosporina) liberate their spores in the same way, but whereas the coiled thread in these cases is frequently as long as $7 \mathrm{~mm}$., the thread in Gnomonia is less than a millimetre in length. When one of these threads of spermatia is put into a drop of water it becomes broken up into the innumerable spermatia of which it is composed. Doubtless in nature spermatia are scattered over the under surface of the affected area of the leaf by the action of rain or dew.

Spermatia have been frequently seen adhering to the trichogynes whose structure will be described later (cf. Figs. 7, 8). It may be said here, however, that the trichogynes pass out of the stomata in compact groups of two to five. In most cases observed, not one, but several, spermatia were found to be attached to one group of trichogynes. When one considers the enormous numbers of spermatia produced and the close proximity of the gelatinous trichogynes to the spermogenia, one recognizes that it is difficult for the trichogynes to escape having spermatia adhering to them.

A large number of sections prepared during two successive years have been examined, but no definite evidence has been obtained for the passage of spermatial nuclei down the trichogynes. Occasionally what appear to be spermatial nuclei are seen embedded in the disorganizing matrix of the trichogynes and even at some considerable distance from their extremities. It is, however, a matter of great difficulty to be certain of the identity of such bodies at this stage because the degenerating nuclei of the trichogynes become elongated and, when stained, simulate the spermatial nuclei themselves.

Attempts have been made to induce the spermatia to germinate, but without success. After prolonged immersion in water and various nutritive solutions they did not show the least indication of further development. Indirect evidence as to the lack of germinative power possessed by these spermatia is obtained from the circumstance that no newly infected areas appear on the leaves after spermogonial formation. Of course one must not lay too much stress upon the apparent inability of these spermatia to germinate, because it is well known that the spores of many parasitic fungi are often erratic in their germinative capacity.

Upon considering the above data one is compelled, I think, to conclude that the spermatia of Gnomonia erythrostoma are abortive structures of the nature of male cells. Frank (17) came to the conclusion that they were male cells chiefly upon the ground that he had seen them attached to the trichogynes. The above account of their cytological characters and other facts cited in regard to them demonstrate more clearly what their nature is. V. H. Blackman (1) has shown that the spermatia of the Uredineae possess 
the cytological characteristics of male cells-viz. a relatively large nucleus, a small amount of cytoplasm, and absence of food-reserves. The cytological features of the spermatia of Gnomonia are identical with these. One can also point to the striking similarity in general structure between the spermogonia of Gnomonia and those of the Uredineae. The fact that no success has attended one's efforts to induce the spermatia of Gnomonia to germinate is in keeping with the inability exhibited by the spermatia of the Uredineae to undergo further development under all conditions approximately normal.

In this connexion it is interesting to compare the cytological characters of the pycnidiospores of a species of Phyllosticta frequently found associated with Gnomonia on old Cherry leaves. Phyllosticta is a genus belonging to the Sphaeropsidales. The pycnidiospores of this genus readily germinate. Fig. $6 a$ shows some of stained spores of the species of Phyllosticta found on old Cherry leaves. It will be observed that the relation between the size of the nucleus and the amount of cytoplasm is radically different from that holding in the spermatium of Gnomonia.

The fact that in Gnomonia some spermogonia are always produced before the formation of the coiled structures (to be described later) is what one would expect if the spermatia at present or in the course of recent phylogeny performed a fertilizing function. In the Rusts, too, one finds that the formation of spermogonia precedes that of aecidia.

Some authorities, e. g. Brefeld (4) and Christman (5), hold that the spermatia of the Uredineae are simply asexual spores which have lost the power to germinate; but their cytological characteristics, as first demonstrated by Blackman, seem to negative this view.

\section{Trichogynes and Ascogonia.}

Soon after the beginning of the formation of spermogonia, groups of hyphae towards the lower epidermis begin to entwine themselves closely together and so form the 'coils' (i. e. the 'Knäuel verflochtener Fäden' of Frank) which are the earliest stages of perithecial development (Fig. 8). The hyphae which become compacted into these 'coils' cannot be distinguished from vegetative hyphae. The 'coils' are roughly spherical in shape, but they differ much in size, their diameter varying from $40 \mu-100 \mu$. It is generally found that certain hyphae connected with the periphery of the 'coils' pass out through a stoma. These hyphae, the trichogynes of Frank (17), are most often grouped together in a compact bundle of two to five which protrudes slightly from the stoma. The trichogynes passing through any one stoma are closely compacted together in the apical region (Figs. 7, 8). The group becomes somewhat narrowed while passing through the stoma, but when clear of it expands again and terminates as a domeshaped mass (Fig. 7). The cell walls at the tips of the trichogynes become 
swollen and apparently mucilaginous, as do also the lower lateral walls to a lesser extent.

The tufts of trichogynes are generally placed laterally in relation to the 'coils'. Thus it is rare to see a group of trichogynes over the middle of a 'coil'. It is often evident that at least two series of trichogynes are associated with a single 'coil', but only very rarely are two such groups seen in a single section. In all cases examined it was only possible to trace a connexion between the trichogynes and the outermost cells of the 'coil'. The trichogynes could never be traced to any structures resembling ascogonia, so must therefore be looked upon as mere continuations of ordinary vegetative hyphae belonging to the 'coil'. Fisch (15) and Frank (16) state that in Polystigma rubrum the trichogyne is the termination of a clearly differentiated archicarp. In this respect, therefore, Gnomonia differs considerably from Polystigma.

The apical cell of each trichogyne is long and narrow, and generally contains a single nucleus (Fig. II); occasionally a second nucleus is present. The first septum below the extremity of the trichogyne is approximately at the level of the inner wall of the epidermal cells, and below this region the identity of the trichogyne is lost, so that as a well-marked structure it is only one cell in length. It may be pointed out that the uninucleate condition of the apical cell of the trichogyne is the same as that found by Baur $(a)$ in the corresponding structure of Collema, and by Darbishire (12) in Physcia. On the other hand, all the cells of the hyphae beneath the terminal cells of the trichogyne are multinucleate and, as has already been said, are scarcely distinguishable at the time of their formation from cells of the general mycelium.

At a later stage a few cells in the midst of the 'coil' become differentiated from those around by their larger size, their denser protoplasm, and by their larger and less numerous nuclei (Figs. 9, IO, II I I4). Though these cells often appear to be isolated from each other in a single section they really belong to one or more twisted filaments, as is ascertained by examining successive sections. No pores such as occur in the archicarps of Ascobolus (32) and Ascophanus (7) have been observed between the contiguous cells of these filaments.

The nuclei of these special cells usually possess a distinct nucleolus, but no reticulum is visible, while the nuclei of the cells around contain several small chromatin granules and the nucleolus when present is very small. Furthermore, they are about twice the size of the vegetative nuclei. Nuclei of an intermediate character are sometimes visible in the larger cells in the centre of the 'coil'. Occasionally one or two exceptionally large nuclei are found in these differentiated cells. Such nuclei contain several deeply staining chromatin granules, but no well-marked nucleolus (cf. Fig. II). It may be that these nuclei have grown immensely in size prior to division, but on the other hand they may be hypertrophied. 
It is considered that the nuclei present in the differentiated part of the ' coil ' have become larger in size by a process of growth, no fusion having been observed before their occurrence. By comparison with certain Lichens and with Polystigma these larger cells in the midst of the 'coil' are to be interpreted as ascogonial cells, while the surrounding cells are purely nutritive and protective in function. On the other hand the ascogonial cells are not so clearly defined in Gnomonia as in the Lichens and in Polystigma. There can be no doubt that in Gnomonia more than one ascogonium is usually present in the 'coil', which later gives rise to a single perithecium ; while in Polystigma, according to Fisch and Frank, the perithecium generally develops in association with a single ascogonium.

It has already been mentioned that spermatia in considerable numbers have been seen attached to the trichogynes. No evidence was obtained that the nucleus of a spermatium fused with the single nucleus usually present in the terminal cell of a trichogyne, or that it passed downwards to the larger ascogonial cells. In fact the single nucleus of the apical part of the trichogyne often shows signs of disorganization as soon as the trichogyne has passed beyond the stoma, and this unhealthy condition frequently extends to several of the nuclei in the cells immediately below. Frank states in his account of Polystigma rubrum that where spermatia adhered to the trichogynes the former seemed to be poorer in contents. He concluded from this that the nuclei of the spermatia passed into the trichogynes and performed a fertilizing function. It would appear, however, that the apparent diminution of protoplasmic contents might be just as readily explained by the process of disorganization which the spermatia would naturally undergo if they remained for any length of time on the exposed trichogynes. It is clear that the mere adhesion of spermatia to the trichogynes is no evidence for their fertilizing function.

During this investigation of Gnomonia, coils, apparently normal, have been frequently seen, to the trichogynes of which no spermatia were adhering. A more surprising phenomenon has been observed in that the trichogynes sometimes grow out from small groups of hyphae in which no ascogonia can be seen, and which therefore cannot be considered to be of the same nature as the 'coils'. Trichogynes have also been seen growing from ordinary hyphae which were not massed together (Fig. I2). Frank also mentions this fact, but appears to attach no significance to it. The nuclei of the cells in immediate connexion with such trichogynes are in no way different from ordinary vegetative nuclei. It was not only in material gathered early in the season that trichogynes were found apart from the 'coils', but that obtained much later showed the same phenomenon. Hence the view that the vegetative cells below these trichogynes develop later into 'coils' cannot be entertained.

I observed also a group of trichogynes in connexion with the margin 
of a spermogonium. In addition to this anomalous behaviour, trichogynes have also been seen undergoing further development as vegetative hyphae (Fig. I3). Such behaviour of the trichogynes militates strongly against the view that they are functional receptive organs. The question of their present function will be considered later.

Careful search was made amongst the ascogonial cells of the 'coil' to see if there was any fusion of nuclei in pairs similar to that which takes place in the ascogonium of Humaria gramulata described by Blackman and Fraser (3), or in the more similar multicellular ascogonium of Ascophanus carneus recently described by Cutting (7). No such process, however, was observed.

The 'coils' may develop into perithecia in the autumn or may remain throughout the winter in the same condition. Fig. I5 shows a section through a portion of a ' coil' in the resting stage. It will be noticed here that two types of cells are present, viz. those with dense cytoplasm and large nuclei, and those with highly vacuolate protoplasm and smaller nuclei. I conclude that the former are the cells previously described as being ascogonial in nature. Fig. 16 also represents a section of a 'coil' in the resting condition.

\section{The Development of the Perithecium.}

Frank states that the perithecia develop from the 'coils' in the autumn, though he suggests that the asci do not ripen until later. My experience has been, however, that there is no one definite time for the development of the perithecia from the 'coils'. The change of 'coils' into perithecia has been found to occur as early as November, while in other cases resting coils have been seen as late as March.

The first thing to be observed in the further development of the 'coil' is the growth of cells in the lower middle part, i. e. the region which is remote from the trichogynes. The cells in this position send out branches which grow towards the lower epidermis of the leaf. A few of the cells above are often seen to be disorganizing. About the same time the cells towards the periphery of the 'coil ' increase in number, thicken their walls, and thus become differentiated at an early stage to form the wall of the perithecium. These cells contain food reserves which are probably of an oily nature, since they blacken with Flemming's fixative; the protoplasmic contents, however, of these cells are poor. A cavity has by this time appeared towards the upper part of the developing perithecium. This is formed probably as the result in the main of the greater expansion of the outer tissues.

It is a matter of great difficulty at this stage to trace the remains of the ascogonia. Only occasionally does one find at the periphery of the perithecium an unusually large cell containing nuclei of about the same size 
and general appearance as those described above in ascogonial cells. The difficulty of tracing the ascogonium at this period arises from the fact that in Gnomonia it is such a poorly differentiated structure. In spite of prolonged search no evidence could be obtained for the development of asci from ascogonia, and in fact after this stage the latter cannot be traced at all. It would seem, therefore, that in Gnomonia the ascogonial cells are no longer functional. Fisch (15) states that in the allied fungus Xylaria polymorpha the ascogonial cells disorganize during the young stages of perithecial development, and that the ascogenous hyphae arise de novo. Traces of functionless ascogonia have also been found in Otidea aurantia $(20 \mathrm{a})$ and in certain Lichens.

The branches previously put out from the lower middle part of the ascocarp continue their growth towards the region which later becomes the neck of the perithecium. These branches vary considerably in width, but usually they are nearly as broad as the asci which are formed later. They are occasionally septate and are of irregular growth (Fig. I7). Their cells are poor in cytoplasm, and their nuclei are not to be distinguished from the usual vegetative nuclei. These threads disorganize before the asci come to maturity. The width, the irregular growth, and the early disorganization of these threads all indicate that they cannot be looked upon as typical paraphyses. In fact, Gnomonia erythrostoma has no ordinary paraphyses when the asci are mature. The appearance of these outgrowths is striking, and at first sight they suggest asci which have developed abnormally; their function is obscure, although they may take a part in the formation of the cavity of the perithecium. They do not appear to have been described elsewhere.

At a later stage, short hyphae with dense cytoplasm and several deeply staining nuclei become distinguishable towards the base of the perithecium (Plates XLVIII and XLIX, Figs. I 8, I9). The asci invariably take their origin from these hyphae. Though it was difficult to obtain certainty in the matter, close investigation pointed strongly to the conclusion that these ascogenous hyphae grow out directly from vegetative cells at the base of the perithecium. Such a development is the natural corollary of the disappearance of the ascogonia in earlier stages. In the process of differentiation of the ascogenous cells from vegetative cells the cytoplasm becomes denser; the nuclei become larger, and contain a more definite chromatin network and also a distinct nucleolus. No fusion has been observed prior to the formation of these clearly differentiated nuclei.

The gradual increase in size of the nuclei in these ascogenous cells would thus appear to be due to a process of growth alone. Fig. I 8 shows some of these nuclei which are becoming differentiated from ordinary nuclei.

Sometimes the larger nuclei of these ascogenous cells are arranged irregularly in relation to each other, but more often they appear to be 
associated in pairs (Figs. 20, 22). This state possibly indicates a conjugate condition of these nuclei, but in the absence of preparations showing nuclear divisions at this stage-apart from one doubtful case (Fig. 2I), it is impossible to speak with certainty. In this doubtful case the difficulty of determining the connexion of the cell in which it occurs prevents one from deciding whether this conjugate division is the one immediately before the formation of the young ascus or one at an earlier stage. The cells that contain the larger nuclei branch, and so the number of ascogenous cells is increased. Fig. 22 shows this branching. The ascogenous cells cannot be traced very far because of the intricate way in which all structures at the base of the perithecium are interwoven. Hence to follow the course of the ascogenous hyphae in Gnomonia is a more difficult matter than in Discomycetes generally.

There is a considerable difference in regard to the manner in which the asci arise from the ascogenous cells. Crosier formation, so frequently described for other Ascomycetes, has been seen in Gnomonia also (Fig. 25). Often, however, although the end of the ascogenous cell begins to bend over, this process is not continued, and the terminal part, containing two nuclei which fuse, forms the ascus. Sometimes there is not even a trace of bending over (Figs. 22, 23) before ascus formation. In Fig. 22 it is evident that the penultimate cell grows out laterally to form another ascus. The same process may no doubt go on indefinitely. This mode of ascus formation is similar to that described by Maire (26a) in Galactinia succosa. Faull (14) has also pointed out the differences to be observed in the mode of ascus formation in other Ascomycetes.

The two nuclei present in the young ascus cell lie in contact with each other and soon fuse together (Fig. 27). They seem to melt into each other. The nucleoli, however, do not become united for some time. Immediately after fusion, the nucleus thus formed increases in size and the ascus grows in length.

It should be mentioned here that while the first asci have been in process of formation, the neck of the perithecium has been differentiated by the outgrowth of cells which originally formed the part of the coil towards the trichogynes. The periphyses develop as narrow outgrowths from cells on the inside of the upper part of the ascocarp. As stated earlier, no typical paraphyses are developed.

\section{The Cytology of the Ascus.}

When the ascus nucleus has reached its maximum size, i.e. shortly after fusion has taken place, the chromatin thread becomes densely aggregated towards one side of the nuclear membrane (Fig. 28). At a later stage the thread becomes looser and more generally distributed. It has been 
often observed that the chromatin network is not readily stainable at this stage (Fig. 29). This condition apparently persists for some time. The exact method of formation of the chromosomes of the first division could not be made out. No indications of loop formation have as yet been observed. Fig. 30 shows one of the few stages seen in the formation of the chromosomes. It will be observed that four lumpy masses are being elaborated within the nuclear area. Spindle formation takes place in the same manner as that described by Harper (24) and Fraser (19) in other Ascomycetes. Distinct centrosomes of a discoid shape are present at the two extremities of the spindle (Fig. 33). While the chromosomes are in process of formation the nucleolus becomes vacuolate (Fig. 30 ), and the nuclear membrane less clearly defined. Figs. 3I-33 show the metaphase of the first division. In some cases the shape of the chromosomes of this division is strikingly like that of the heterotype chromosomes of pollen mother-cells (Fig. 34). They are short and thick, and in metaphase show a middle portion projecting equatorially and two limbs directed along the spindle. Fig. 35 shows a late stage in the first division. This nuclear division is therefore to be interpreted as being one of reduction, though whether it is heterotypic or brachymeiotic one cannot say with certainty, since the exact details of chromosome-formation have not been ascertained. The shape of the chromosomes and the fact that the second division follows rapidly upon the first furnish analogies with meiosis rather than with brachymeiosis.

In the reconstruction of the two daughter-nuclei a distinct nucleolus is formed (Fig. 36). Preparations showing the metaphase and anaphase of the second division have not yet been obtained, but the telophase is represented in Figs. 38,39 .

The four nuclei thus formed rest for some time before undergoing the next division. The chromatin network of these nuclei is clearly marked. The nuclei often show a certain amount of polarity at this stage and a little later. Thus in Fig. 40 one nucleus shows the attachment of the chromatin net to one end of the nuclear membrane. Such a condition reminds one of the ascus nuclei of Phyllactinia, where Harper found very distinct polarity. A slight polarity has also been seen in the bi-nucleate stage of the ascus of Gnomonia. No clear contraction of the chromatin network, such as has been described as occurring in some cases in connexion with brachymeiosis, was seen in the prophase of the third division nor indeed at any stage subsequent to the first division. In the third division, the spindle is generally orientated at right angles to the long axis of the ascus, but not invariably so. During the metaphase of this division the chromosomes are arranged on the equatorial plane of the spindle in the manner usual in karyokinesis (Fig. 42). The anaphase is represented in Fig. 43, and the telophase in Fig. 44. In reference to Fig. 43 it should be stated that the preparation was made from material which had been lying damp in the laboratory for some days, whereas 
most of the other preparations have been obtained from material fixed directly upon arrival at Cambridge. There is no reason, however, for thinking that this preparation represents an abnormality.

From an examination of these figures there would appear to be no reduction in number of chromosomes at this stage such as there is in the brachymeiotic phases described by Miss Fraser in Humaria rutilans and by Miss Fraser and Miss Welsford in Otidea aurantia, \&c.

The number of chromosomes appears to be usually four after the contraction of the first division. This number certainly seems to fit the phenomena observed better than any other number or numbers. On the other hand, there seems to be some evidence-not very definite as yet it is true, that the chromosome number in Gnomonia is not strictly constant. Still the preparations necessitate the consideration of this view. Furthermore, the shape of the chromosomes would appear to be variable in this fungus. Without considering the chromosomes of the first division, one has seen that they are sometimes long and thread-like, and at other times short and thick. In addition the extraordinary power of increase in size possessed by the nuclei is worthy of mention.

After the reconstruction of the eight nuclei each puts out a beak-like process similar to that described by Harper in Lachnea seutellata and other Ascomycetes. The astray rays become more conspicuous and bend down towards the other end of the nucleus. The exact mode of delimitation of the spores, however, could not be made out. A certain amount of epiplasm is left as in other Ascomycetes. After the spore membrane has been laid down, the nucleus undergoes a period of rest subsequent to which another nuclear division is effected. This division usually takes place towards the base of the spore. Fig. 45 shows this division. The number of chromosomes would appear to be four at this stage also. One of the daughter nuclei thus formed passes to the extremity of the spore which is towards the base of the ascus, and a septum is laid down between the two nuclei cutting the spores into cells of unequal size (Fig. 46). The nucleus of this tail-cell gradually disorganizes. It is interesting to note in this connexion that in all experiments made upon the germination of the ascospores it was only the larger cells of the latter which put out germ-tubes. The larger cell of each ascospore contains two conspicuous oil drops at maturity.

In considering the nuclear phenomena in the ascus as a whole, one is led to the conclusion that there is a single process of reduction which is effected during the first division. There is no evidence yet that a second reduction is effected at a later stage. Nor is there any obvious pairing of chromosomes which might obscure such a process.

On the evidence yet available one cannot decide whether the first division is heterotypic or brachymeiotic in nature, though certain phenomena already mentioned would appear to favour the former interpretation. 
The single process of reduction in the ascus is in harmony with the single nuclear fusion which appears to occur in this form.

\section{General Considerations.}

From the observations recorded earlier in the paper, one is led to conclude that the 'coils' develop into perithecia without undergoing any process of fertilization by means of the spermatia. It is possible, of course, that this process has been missed. Even if such a fertilization did occur, it would be extremely difficult to demonstrate, both on account of the collective grouping of the trichogynes and the intricacy of the coiled structures. In view, however, of the care which has been taken in order to obtain the earliest stages of development of the sexual organs, I do not think this process can have been missed. As has been said before, the mere adhesion of spermatia to the trichogynes is no evidence that fertilization occurs, for under the conditions of growth it would be surprising if most of the trichogynes did not have spermatia attached to them. Besides, it is difficult to imagine how the spermatia can pass down to the ascogonial cells in view of the fact that no pores appear to exist in the cell-walls between the trichogynes and the cells beneath.

The most probable view is that the spermatia were originally the agents of fertilization. Their cytological characters and other evidence in regard to their behaviour point to this conclusion. The spermogonium of Gnomonia is to be looked upon as a sorus of functionless male organs similar to that which is so often found in the Uredineae. Such a collection of male organs may perhaps be compared to the male conceptacles of certain Florideae (e. g. Corallina).

The trichogynes are looked upon as having originally functioned as receptive organs for the ascogonial cells, though my observations indicate that they do not thus function at present. Other functions have been attributed to the trichogynes which are present in certain Lichens, e.g. Collema, Physcia. Thus Van Tieghem (30) considered that the trichogynes of these Lichens were really respiratory organs. It is difficult to conceive that this was the original function of such trichogynes because there are many Lichens and innumerable Rusts, and other fungi parasitic on leaves, which at present exhibit no trace of such structures. Lindau (26), on the other hand, assumes that the trichogynes in the case of the Lichens serve a mechanical function in preparing apertures for the ascocarps which arise later. This explanation will not account for the occurrence of trichogynes in Gnomonia where the perithecia are not developed until after the 'coil' has undergone a prolonged resting stage. Though I consider the original function of the trichogynes was that of receptive organs, it is possible that they serve at present some secondary purpose. Thus, the production of trichogynes which have no connexion with 'coils' may be explained by their 
functioning in a secondary manner as respiratory organs. One naturally supposes that as the leaf of the host becomes first yellow, and then brown, the assimilatory process dwindles, until no oxygen at all is liberated, while the evolution of carbon dioxide continues for a time. Such phenomena may very well necessitate the growth of certain hyphae through the stomata to the outside atmosphere. Vuillemin (31) records the interesting fact that in the genus Hypostomum, parasitic on the leaves of Conifers, structures considered by him to be analogous to trichogynes are produced, although no spermogonia are present. This also points to the possibility that the trichogynes may now perform a function which was not their original one.

This investigation leads one to look upon the ascocarp of Gnomonia as a structure formed in relation to one or more ascogonia in close connexion with one another. This association of two or more ascogonia before the development of the perithecium is paralleled in the Discomycetes by Pyronema confluens (23) in which several pairs of sexual organs co-operate to give rise to a single apothecium. Stahl (28) states also that in the Lichen genus Physma, several archicarps go to produce one apothecium. Many other Pyrenomycetes show the presence of definite archicarps before the formation of perithecia, but in these the female organs normally arise separately one from the other. Fisch (15) states, however, that in Polystigma rubrum, two ascogonia with their trichogynes may arise in close association. The ascogonia of Gnomonia erythrostoma seem to be more closely allied to those of Polystigma rubrum than to those of any other Ascomycete as yet investigated. Coiled ascogonia have been described also by Kihlmann (25) as occurring in Melanospora parasitica, by Miss Dawson (13) in Poronia punctata, and by Fisch (15) in Xylaria polymorpha. In Poronia, however, the trichogyne portion is not always present, and in Xylaria it is constantly absent. Fisch states, in regard to the latter, that the asci arise independently of the ascogonia as they would appear to do also in Gnomonia. He found that in Clavicepspurpurea there was no trace of an ascogonium, so that in the series mentioned there is an evident reduction in the formation of the female organs. When one considers the Lichen genera Collema and Physcia, one sees some resemblance between the general form of their ascogonia and those of Polystigma and Gnomonia. These four genera are all characterized too by the production of spermogonia. The cells of the ascogonia of these Lichen genera are uninucleate as described by Baur $(a)$ and Darbishire (12) respectively, a condition in marked contrast to the multinucleate nature of the ascogonial cells of Gnomonia. Baur states that in Collema crispum the successive cells of the trichogyne are clearly connected by strands of protoplasm at the time which he considers to be that of fertilization. He infers that the pores through which these strands pass enable the spermatial nucleus to pass down to one of the ascogonial nuclei below. In Gnomonia no such phenomenon has been observed, and the fact that the ascogonia at a later stage 
can no longer be traced is against such a possibility. There is circumstantial evidence in the case of Collema crispum in favour of fertilization by means of spermatia, because Baur $(a)$ found that of the two kinds of thallus present in this species, that which bore both spermogonia and archicarps gave rise to apothecia, whereas the thallus which did not possess spermogonia only very rarely developed the ascus fructifications. It would seem, however, that until a fusion of nuclei has been observed it is not safe to conclude that fertilization has taken place by an external means. When the pores are produced between the cells of the ascogonium of Collema, that structure becomes a coenogamete, and development may proceed by the fusion of nuclei in pairs as occurs in Humaria gramulata. Another possibility is, that only one nuclear fusion, that immediately prior to the development of the ascus, occurs.

Claussen's recent work on Pyronema confluens (6) which, however, requires confirmation, must be taken into consideration. He considers that in this species the male and female nuclei do not actually fuse in the ascogonium but merely remain closely associated together, while in the ascogenous hyphae these paired nuclei divide in a conjugate manner, nuclear fusion only occurring just before the formation of the ascus. Blackman and Miss Fraser have, however, both pointed out that even if Claussen's work holds good for Pyronema a mistake in the interpretation of a first nuclear fusion in the ascogonium can scarcely have been made in the examination of the uninucleate sexual organs of the Mildews, Sphaerotheca (22) and Phyllactinia (24). Besides, so many observers have independently recorded the fusion of nuclei in pairs in multinucleate ascogonial forms, e. g. Humaria gramulata (3), Lachnea stercorea (18), Aspergillus repens (9), Ascophanus carneus (7), \&c., that stronger evidence than has yet been urged by Claussen (6) will be needed in order to disperse the usual view of the presence of two nuclear fusions in many forms. The process of brachymeiosis following that of meiosis discovered by Miss Fraser (19) also supports the occurrence of two nuclear fusions in the life-history of those Ascomycetes in which this process of reduction has been observed.

As has already been stated, there is no evidence that the ascogonia of Gnomonia are functional in that they give rise to ascogenous hyphae, the latter indeed appearing to arise by the subsequent differentiation of ordinary cells. It will be remembered that Fisch has described the degeneration of ascogonia in Xylaria polymorpha, so that these two Pyrenomycetes would appear to be similar in this respect. In Claviceps and Pleospora, according to Fisch and Bauke ${ }^{1}$ respectively, the formation of female organs is entirely in abeyance.

The absence of any indications of nuclear fusion in Gnomonia erythrostoma until ascus development occurs induces one to entertain the view that

1 Bauke: Zur Entwickelungsgeschichte der Ascomyceten. Bot. Zeit., I877. 
in this species only a single nuclear fusion takes place. ${ }^{1}$ It would seem that the sexual fusion which doubtless originally occurred in the ascogonia- of Gnomonia has been replaced by a fusion immediately before the formation of the asci. There is a slight indication that a period in which the nuclei may be conjugately arranged precedes the actual fusion. If this is really the case, the commencement of the sexual process must be looked upon as beginning with the association of nuclei in pairs, as Blackman (1) has pointed out for the Uredineae. It would be premature at present to discuss the possible means by which the transference of the sexual process might have been brought about in the course of phylogeny. Only a single process of reduction in the ascus of Gnomonia has been observed. This harmonizes with the single nuclear fusion which has alone been seen.

The nuclear phenomena described for Gnomonia seem to indicate a closer parallelism between Gnomonia and the Uredineae than has yet been determined for other Ascomycetes. The origin of the binucleate phase in the Uredines has been shown to take place in more than one way, and in some forms possessing deeply-seated aecidia it is possible, from the recent work of Olive, ${ }^{2}$ that the binucleate phase originates in multinucleate cells at the base of the aecidium. If this prove to be the case, the cytological behaviour would appear to be somewhat similar to that of Gnomonia. Such a similarity between the nuclear phenomena of some of the Uredineae and a member of the Ascomycetes is of great interest, but in the present state of our knowledge it can hardly be made the basis for phylogenetic speculations as to the relationship of these two groups. On the other hand, the closest relationships of the Uredineae are certainly with the other Basidiomycetes. It is recognized that expressions of opinion on the phylogeny of the fungi must be highly speculative from the very nature of these organisms. Therefore one hesitates to state the possibility that the Uredineae-true Basidiomycetes as they undoubtedly now are-may have been connected with the Ascomycetes in the course of phylogeny.

\section{SumMary.}

I. The vegetative mycelium consists of multinucleate cells. It is intercellular. Haustoria are not developed.

2. The spermogonia are similar in structure to those of the Uredineae. The spermatia are long and thread-like, and possess the cytological characters of male cells. They are considered to be now functionless, there being no evidence that fertilization is effected by their agency as Frank supposed.

3. The trichogynes arise in tufts of $2-5$, and do not invariably arise in

${ }^{1}$ It is possible that an earlier fusion has been missed, though in view of the careful search made for such a process this is unlikely.

${ }^{2}$ Olive, E. W. : Sexual Cell Fusions and Vegetative Nuclear Divisions in the Rusts. Ann. Bot., xxii, 1908. 
association with 'coils'. It is suggested that the trichogynes, though originally the receptive organs, now perform a different function, possibly a respiratory one.

4. The 'coils' are the first beginnings of perithecial development. In the centre of each 'coil' one or more slightly differentiated hyphae are found. The latter are considered to be of the nature of ascogonia. No clear connexion can be traced between the trichogynes and the ascogonia.

5. The stages in the development of the perithecium from the 'coil' are described. During these processes it is no longer possible to trace the ascogonia. The ascogenous cells appear to arise by differentiation from ordinary cells.

6. The only nuclear fusion that has been observed takes place in the young ascus.

7. The nuclear divisions in the ascus are described. Only a single process of reduction has been seen. This occurs in the first division. It is not possible to decide whether this division is heterotype or brachymeiotic, though the analogies seem to be with the former rather than the latter.

8. Thus Gnomonia erythrostoma would appear to be an Ascomycete in which only a single nuclear fusion and a single reduction occur normally in the life-cycle.

Botany School, Cambridge, June, rgro.

\section{LIST OF PAPERS.}

a. BAUR, E. ('98): Zur Frage nach der Sexualität der Collemaceen. Ber. d. Deut. Bot. Gesell., xvi.

1. Blackman, V. H. ('04) : On the Fertilisation, Alternation of Generations, and General Cytology of the Uredineae. Ann. Bot., xviii.

2. Blackman, V. H., and Fraser, H. C. I. ('05): Fertilisation in Sphaerotheca. Ann. Bot., xviii.

3.

('06): On the Sexuality and Development of the Ascocarp in Humaria gramulata. Proc. Roy. Soc., London, B. 1xxvii.

4. BREFELD, O. ('72 et seq.) : Untersuchungen aus dem Gesammtgebiete der Mykologie. Leipzig.

5. Christman, A. H. ('05): Sexual Reproduction in the Rusts. Bot Gaz., xxxix.

6. Claussen, P. ('07): Zur Kenntniss der Kernverhältnisse von Pyronema confluens. Ber. d. Deut. Bot. Gesell., xxv.

7. Cutring, E. M. ('09): The Sexuality and Development of the Ascocarp of Ascophanus carneus. Ann. Bot., xxiii.

8. Dale, E. ('03) : Observations on the Gymnoascaceae. Ann. Bot., xvii.

9. ('09): On the Morphology and Cytology of Aspergillus repens. Ann. Myc., vii.

10. Dangeard, P. ('94-95): La Reproduction sexuelle des Ascomycètes. Le Botaniste, iv.

11.

('04): Recherches sur le développement du Périthèce ches les Ascomycètes. Le Botaniste, ix. 
12. Darbishire, O. V. ('99): Ueber die Apothecienentwickelung der Flechte Physcia pulverulenta. Jahr. f. wiss. Bot., xxxiv.

13. Dawson, M. ('00): On the Biology of Poronia punctata. Ann. Bot., xiv.

14. Faull, J. H. ('05): Development of the Ascus and Spore Formation in Ascomycetes. Proc. Boston Soc. Nat. Hist., xxxii.

15. Fisch, C. ('82): Beiträge zur Entwickelungsgeschichte einiger Ascomyceten. Bot. Zeit., xl.

16. Frank, A. B. ('83): Ueber einege neue und weniger bekannte Pflanzenkrankheiten. Ber d. Deut. Bot. Gesell., i.

17. ('86): Ueber Gnomonia erythrostoma, die Ursache, \&c. Ber. d. Deut. Bot. Gesell., iv.

18. Fraser, H. C. I. ('07): On the Sexuality and Development of the Ascocarp in Lachnea stercorea. Ann. Bot., xxi.

19. ('08): Contributions to the Cytology of Humaria rutilans. Ann. Bot., xxii.

20. Fraser, H. C. I., and Chambers, H. S. ('07): The Morphology of Aspergillus herbariorum. Ann. Myc., v.

$20 a$. Fraser, H. C. I., and Welsford, E. J. ('08): Further Contributions to the Cytology of the Ascomycetes. Ann. Bot., xxii.

21. Harper, R. A. ('95): Zur Kenntniss der Kerntheilung und Sporenbildung im Ascus. Ber. d. Deut. Bot. Gesell., xiii.

22 . ('95): Entwickelung des Peritheciums bei Sphaerotheca Castagnei. Ber. d. Deut. Bot. Gesell., xiii.

23. - ('00): Sexual Reproduction in Pyronema confluens. Ann. Bot., xiv.

24. ('05): Sexual Reproduction and the Organisation of the Nucleus in certain Mildews. Publ. Carnegie Inst., Washington, No. 37.

25. Kihlmann, O. ('85): Zur Entwickelungsgeschichte der Ascomyceten. Acta Soc. Sc. Fennicae, xiv.

26. Lindau, G. ('88): Ueber die Anlage und Entwickelung einiger Flechtenapothecien. Flora, xlvi. 26 a. Maire, R. ('03) : Recherches cytologiques sur le Galactinia succosa. C. R., Paris, 9 Nov.

27. Salmon, E. S. ('07) : Cherry Leaf Scorch. Journ. Board of Agriculture, London, xiv.

28. Stahl, E. ('77) : Beiträge zur Entwickelungsgeschichte der Flechten. Leipzig.

29. Stoppel, R. ('07): Eremascus fertilis. Flora, xcvii.

30. Van Tieghem, Ph. ('84): Traité de Botanique.

31. Vuillemin, P. : Les bases actuelles de la systématique en mycologie. Progressus Rei Botanicae, I907, p. $4^{6 .}$

32. Welsford, E. J. ('07): Fertilisation in Ascobolus furfuraceus. New Phyt., vi.

\section{EXPLANATIONS OF PLATES XLVIII AND XLIX.}

Illustrating Mr. Brooks's paper on Gnomonia.

All the figures have been drawn with the aid of the camera lucida.

Fig. I. Mycelium of Gnomonia erythrostoma. $\times 680$.

Fig. 2. Single vegetative nucleus. $\times 2,500$.

Fig. 3. General view of spermogonium. $\times 380$.

Fig. 4. Part of spermogonium. $\times 1,300$.

Fig. 5. Fresh spermatia. $\times 400$.

Fig. 6. Spermatium to show structure. $\times 3,300$.

Fig. 7. Tuft of trichogynes. $\times 680$.

Fig. 8. Tuft of trichogynes with 'coil' below. $\times 680$.

Fig. 9. 'Coil' with ascogonium. $\times 680$.

FIG. 10. Central portion of 'coil' showing ascogonium. $\times 680$. 
Fig. II. Central portion of ' coil' showing ascogonium. $\times 2,500$.

Fig. I 2. Trichogyne not connected with a 'coil'. $\times 1,800$.

Fig. I3. Proliferation of trichogynes. $\times 680$.

Fig. I4. 'Coil' cut parallel to leaf surface (only a portion drawn; $a=$ ascogonial cells, $b=$ vegetative cells, cells not drawn are like $b$ ).

Fig. 15. 'Coil' in resting state. $\times 680$.

Fig. I6. 'Coil' in resting state (central part only drawn). $\times \mathbf{I}, 800$.

Fig. I7. Early stage in development of perithecium. $\times 680$.

Fig. I8. Differentiation of ascogenous cell from a vegetative cell. $\times 2,500$. $\times 2,500$.

Fig. I9. Nuclei of young ascogenous cells (other line represents position of perithecial wall).

Fig. 20. Ascogenous cell towards base of perithecium. $\times 2,500$.

Fig. 21. Conjugate division. $\times 2,500$.

Fig. 22. Ascogenous cell and young ascus. $\times 2,500$.

Fig. 23. Ascogenous cell with ascus nucleus. $\times 2,500$.

Figs. 24-26. Stages in formation of asci. $\times 2,500$.

Fig. 27. Nuclear fusion. $\times 2,500$.

Fig. 28. Contraction of net-work in ascus nucleus. $\times 2,500$.

Fig. 29. Ascus nucleus at stage in which net-work stains with difficulty. $\times 2,500$.

Fig. 30. Chromosomes of first division before their arrangement on spindle. $\times 2,500$.

Figs. 3I-33. First nuclear division.

Fig. 34. Separate chromosomes of first division. $\quad \times 2,500$.

Fig. 35. Telophase of first division. $\times 2,500$.

Figs. 36, 37. Binucleate stage (only part of ascus drawn). $\times 2,500$.

Figs. 38,39 . Second division, telophase. $\times 2,500$.

Figs. 40, 4I. Quadrinucleate stage (only two of the four nuclei fully drawn in Fig. 40). $\times 2,500$.

Fig. 42. Third division, metaphase. $\times 2,500$.

Fig. 43. Third division, anaphase. $\times 2,500$.

Fig. 44. Third division, telophase. $\times 2,500$.

Fig. 45. Division in spore. $\quad \times 2,500$.

Fig. 46. Ascus after formation of spores. $\times 680$. 

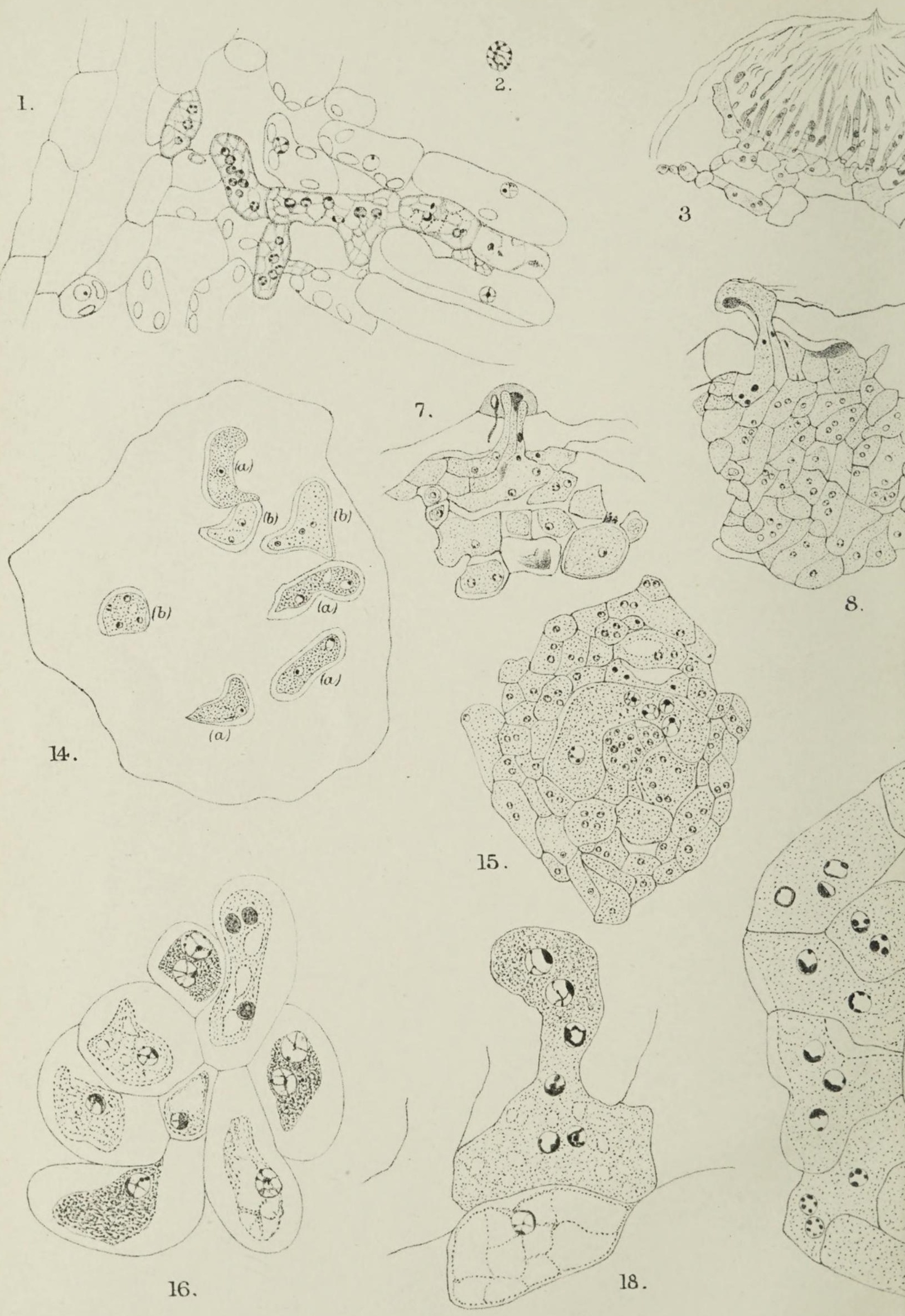

F.T.B. del. 
Annals of Botany

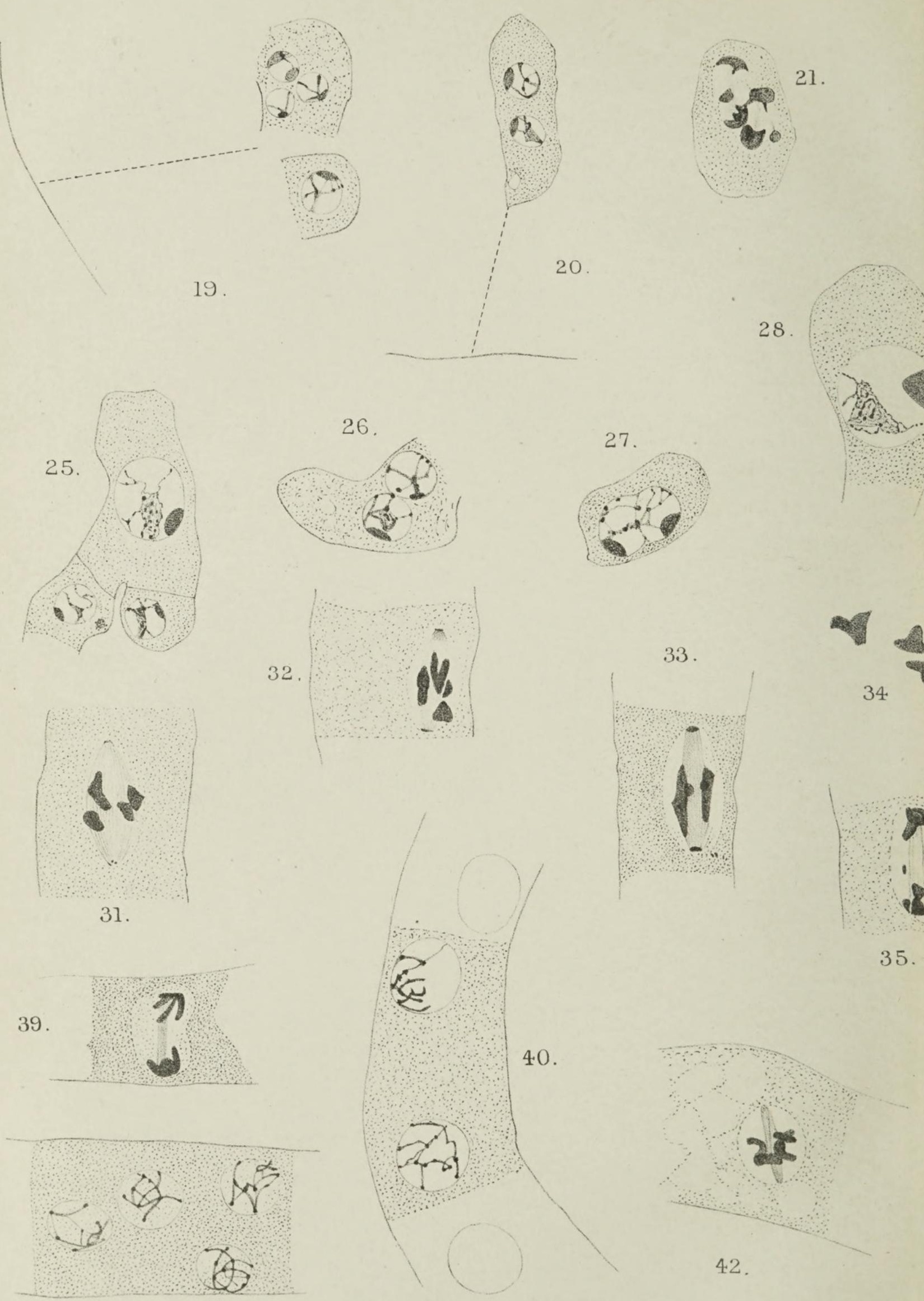

41.

BROOKS GNOMONIA. 
Vol.XXIT.Pl.XIIX.

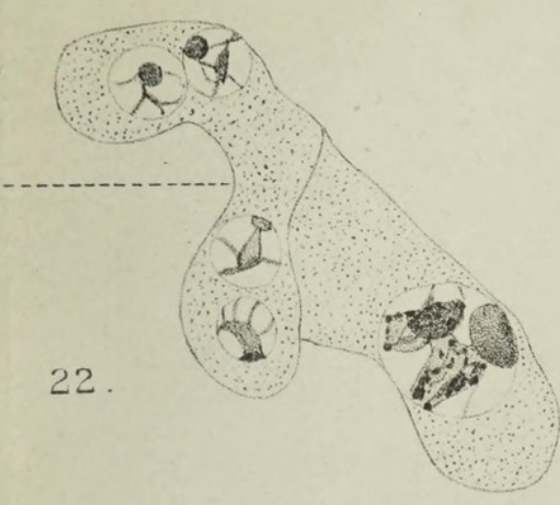

21.

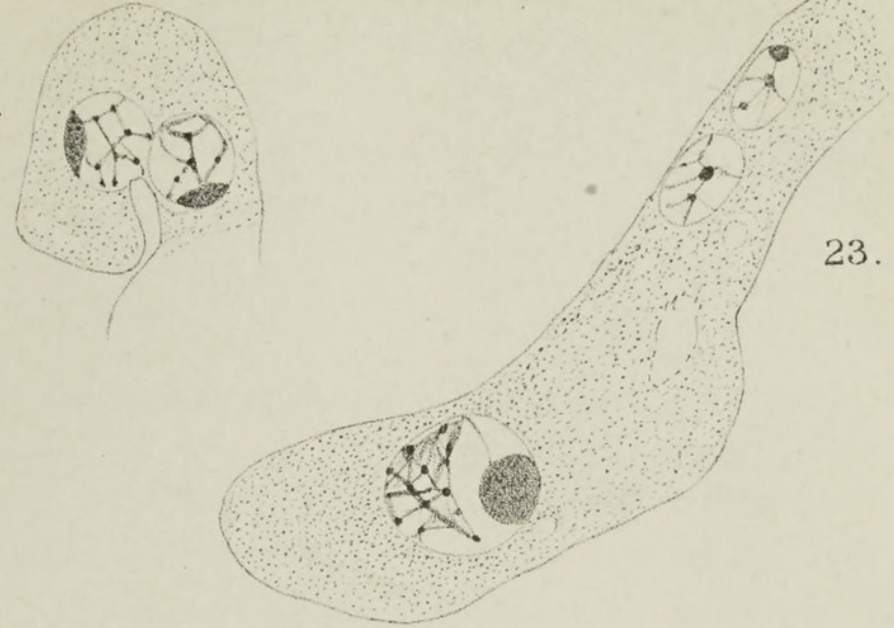

30.
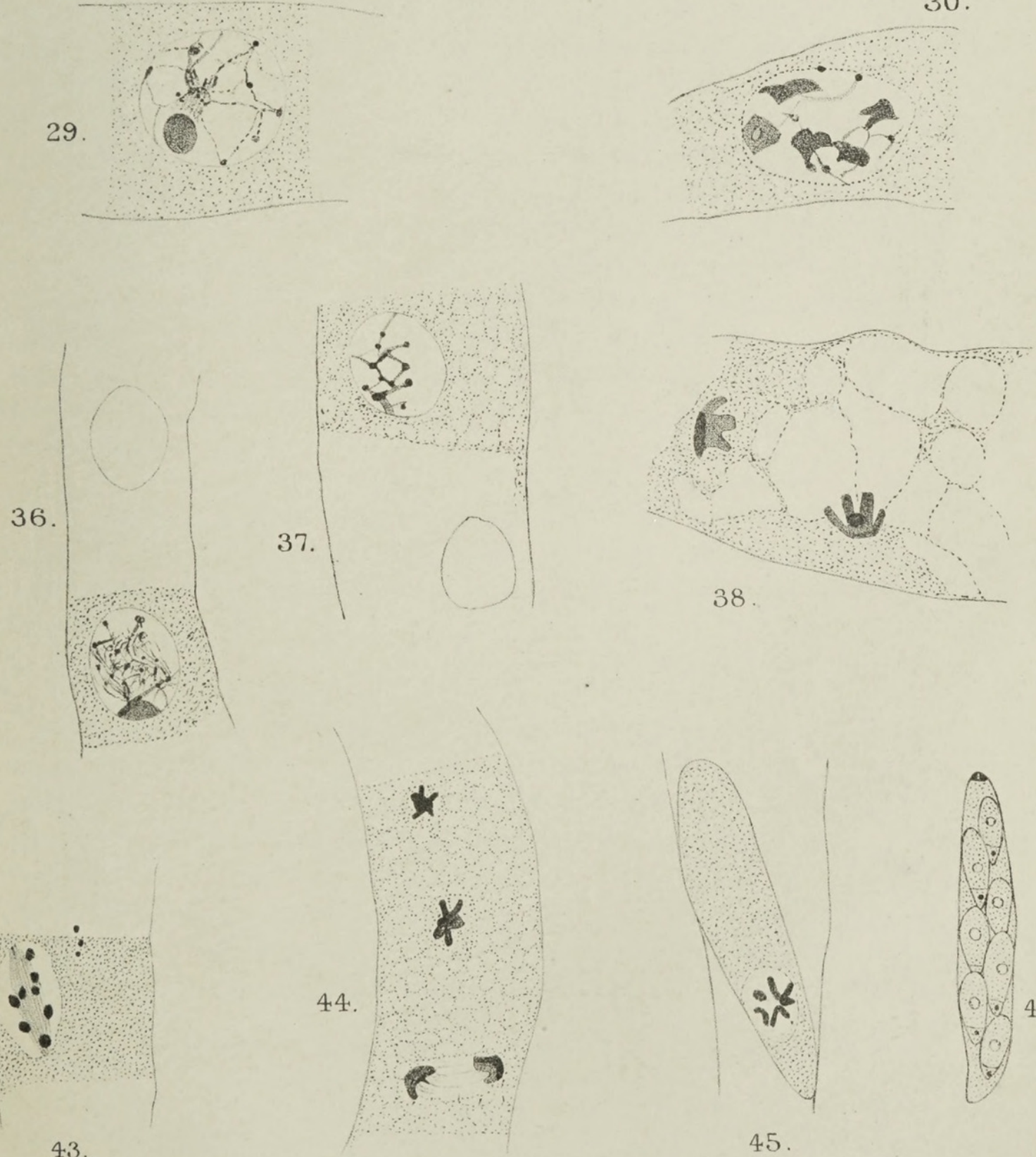
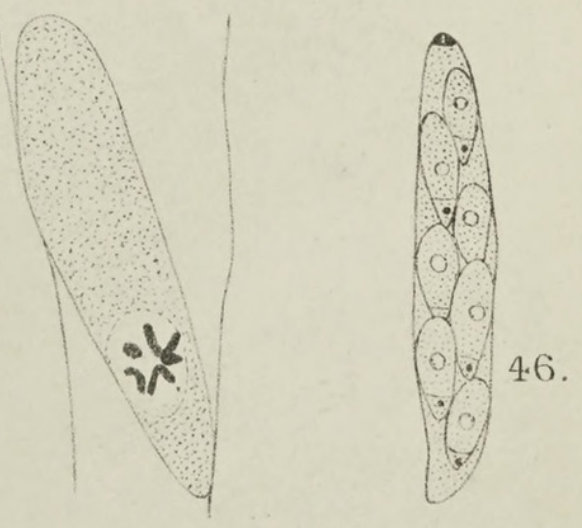

45. 


\section{$2 \mathrm{BHL}$ Biodiversity Heritage Library}

Brooks, F. T. 1910. "The development of Gnomonia erythrostoma, pers. The cherry-leaf-scorch disease." Annals of botany 24, 585-605.

https://doi.org/10.1093/oxfordjournals.aob.a089290.

View This Item Online: https://www.biodiversitylibrary.org/item/262605

DOI: https://doi.org/10.1093/oxfordjournals.aob.a089290

Permalink: https://www.biodiversitylibrary.org/partpdf/319798

\section{Holding Institution}

New York Botanical Garden, LuEsther T. Mertz Library

\section{Sponsored by}

BHL-SIL-FEDLINK

\section{Copyright \& Reuse}

Copyright Status: Public domain. The BHL considers that this work is no longer under copyright protection.

This document was created from content at the Biodiversity Heritage Library, the world's largest open access digital library for biodiversity literature and archives. Visit BHL at https://www.biodiversitylibrary.org. 